\title{
Funding Gap in Hydropower Projects of Nepal: Does Internal Finance Matter?
}

\author{
Kapil Deb Subedi ${ }^{1}$
}

\begin{abstract}
This paper aims to examine the current status of investment and availability of financing to hydro power companies in Nepal. Using pooled cross sectional data of NEPSE listed companies; a regression equation has been estimated to determine the effect of financing constraints on investment decisions of hydro companies. The study results confirm that internal cashflows and leverage are the major determinants of ivestment decisions in Nepalese hydro companies. Moreover, the coefficient of internal cashflow is significantly strong and positive showing its interdependency in financing new investment projects of hydro companies. This relationship strongly supports the financing constraints hypothesis that indicates the capital market frictions as the major obstacle of hydro investment in Nepal. Although the companies have access to banks and foreign capital, still the financing gaps persist and they are highly dependent on their internal cashflows for investment. Additionally, the volatility of cashflows and sales of hydro companies along with their long gestation period pose a significant credit risk to banks and lending institutions that hinder them to provide as much credit as they demand. Besides, the cyclical variations of net worth and collateral values of hydro companies during the tough economic period also resist them to obtain enough finance for further investment. Hence, the government should ensure with appropriate policies, information systems and regulatory mechanism that enable well functioning of capital markets to efficient flows of funds either in the form of equity or debt to boost up the hydropower investment in Nepal.
\end{abstract}

Keywords: Cashflows, Investment, Leverage, Information asymmetry, financing constraints, hydro companies

\subsection{Introduction}

Hydropower is considered as the only feasible reliable and sustainable source of energy in Nepal. In various periodic plans over past decades, Government of Nepal has placed a central focus in hydro energy development, since energy is the catalyst of economic development and essence of modern life of people. Hydro power projects by virtue are capital intensive; require advanced technology and huge finance, hence, it is imperative to develop it through the initiation of private, public and government participation. Besides, the foreign investment has also been felt necessary to fill up the gap in energy demand and supply situation. Particularly, the Electricity Act 1992 and Hydro Power Development Policy 2001 focused necessity of private and foreign investment in the country's power project development. Despite all possible measures taken for attracting private and foreign investment in hydro sector, only $2 \%$ of total feasible hydro energy capacity of the country has been utilized till the end of 2017. Although, Nepal has technical capacity of

1 Mr. Subedi is the HOD, Department of Management at Saptagandaki Multiple Campus, Bharatpur, Chitwan, Email: kapilsubedi11@gmail.com 
Funding Gap in Hydropower Projects of Nepal: Does Internal Finance Matter?

$45610 \mathrm{MW}$ (as shown in table 1) of hydro power generation, the gross production of hydro energy still remains below of 1000 Mega Watt by the end of 2017.

The history of hydro power generation in Nepal has crossed the century, as her first hydro power plant (500 KW) was established in 1911 AD at Pharping, Kathmandu, by the then prime minister Chandra Shamsher Rana of Nepal. Though the first hydro power plant was initiated to fulfill the electricity need of the family members of ruling class, still after the trajectory of 107 years of power development initiation, 94 percent of urban population and only 61 percent of rural population is said to have the access to electricity in Nepal. (Ministry of Finance, Nepal, 2074). Out of installed hydro power projects of Nepal, only 600 MW of electricity has been generated in dry season resulting a heavy dependency of power supply from neighboring country India, the only supplier of electricity to Nepal that transmits $400 \mathrm{MW}$ per day and she is the sole supplier of petroleum products worth more than $\$ 1$ billion per annum making the country in huge trade deficit (10 to 12 times higher import as compared to its total exports to India).

Figure 1- Electricity demand and supply gap in Nepal.

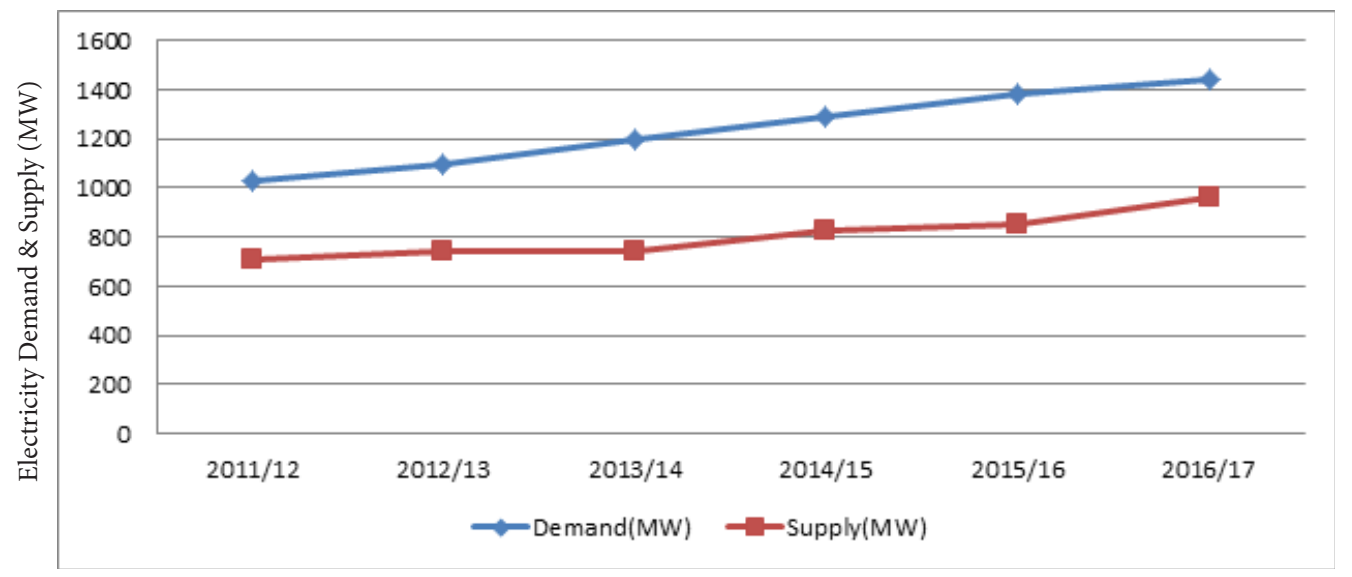

Source - Economic Survey, MOF, Nepal (2074)

The electricity demand in Nepal is growing by 100 to130 MW annually (Ministry of Finance, Nepal, 2074). Currently, electricity demandis 1444 MW at peak time but country has supply position of hardly 961 MW including the $400 \mathrm{MW}$ power imported from India in dry season, making short supply of electricity to $483 \mathrm{MW}$ per day. Meanwhile, the country is in rush of power generation by permitting construction licenses to mega hydro electric projects including Upper Tamakoshi (456 MW), Chamellia (30 MW), Budhi Gandaki (1200 MW), Upper Karnali (900 MW) and Arun Third (900 MW) among others. The power plant installation cost in Nepal is estimated to be 1.5 to 2 million dollar per Mega Watt depending upon the nature of project and type of geographic sites. The country targets to produce $2000 \mathrm{MW}$ electricity per year to turn out the electricity generation goal of $10000 \mathrm{MW}$ in coming five years as per power development plan of Government of Nepal. For accomplishment of such over ambitious target, the country needs to invest at least 4 billion dollar per year (i.e. $15 \%$ of GDP) in power development projects which is almost impossible to finance from internal capital markets. The country needs to appeal and facilitate global power investors in Nepal to overcome such huge financing gaps in power industry. 
Funding Gap in Hydropower Projects of Nepal: Does Internal Finance Matter?

Table 1- Theoretcal, Technical and Economical Hydropower Potential of Nepal

\begin{tabular}{|c|c|c|c|c|c|c|c|}
\hline \multirow[b]{2}{*}{ Major River Basins } & \multicolumn{3}{|c|}{ Theoretical Potential in MW } & \multicolumn{2}{|c|}{$\begin{array}{l}\text { Technical } \\
\text { Potential }\end{array}$} & \multicolumn{2}{|c|}{$\begin{array}{c}\text { Economical } \\
\text { Potential }\end{array}$} \\
\hline & $\begin{array}{c}\text { Major river } \\
\text { courses having } \\
\text { catchments } \\
\text { areas above } \\
1000 \mathrm{~km}^{2} \\
\end{array}$ & $\begin{array}{c}\text { Small river } \\
\text { courses having } \\
\text { catchments } \\
\text { areas } 300- \\
1000 \mathrm{~km}^{2} \\
\end{array}$ & Total & $\begin{array}{l}\text { Number } \\
\text { of } \\
\text { Project } \\
\text { Sites }\end{array}$ & $\begin{array}{c}\text { Technical } \\
\text { Potential } \\
\text { in MW }\end{array}$ & \begin{tabular}{|} 
Number \\
of \\
Project \\
Sites
\end{tabular} & $\begin{array}{l}\text { Economical } \\
\text { Potential in } \\
\text { MW }\end{array}$ \\
\hline Sapta Koshi & 18750 & 3600 & 22350 & 53 & 11400 & 40 & 10860 \\
\hline Sapta Gandaki & 17950 & 2700 & 20650 & 18 & 6660 & 12 & 5270 \\
\hline Karnali and Mahakali & 32680 & 3500 & 36180 & 34 & 26570 & 9 & 25125 \\
\hline Southern River & 3070 & 1040 & 4110 & 9 & 980 & 5 & 878 \\
\hline Country Total & 72450 & 10840 & 83290 & 114 & 45610 & 66 & 42133 \\
\hline
\end{tabular}

Source-Shrestha, H.M. (1966)

In the early years of hydro power development of Nepal, financing of power projects came through grants aid by neighboring countries. For example, India's grants were utilized to construct Trishuli (18 MW), Devighat (14.1 MW), Gandak (15 MW) and Surajpura-Kosi (20MW), Chinese assistance for Sunkoshi (10MW) and former USSR for Panauti (2.4 MW). Since 1970, bilateral and multilateral funds were available for hydropower development. The major donor countries in the period were Japan, Norway, Germany and South Korea including Canada, Finland, Denmark, Sweden and USA. The lending agencies were the World Bank, Asian Development Bank (ADB), Japan Bank for Industrial Corporation (JBIC) former Overseas Economic Co-operative Fund (OECF), Saudi Fund for Development, Kuwait Fund and others. Following the adoption of policy of economic liberalization since 1990 AD, hydropower development took a new turn with the private sector entering the arena (MOWR, 2004).

After promulgation of Hydro Electric Act (1992), private investment called independent power producers (IPP) entered into the sectors along with key contributory Nepal Electricity Authority (NEA) which has constructed major hydro power stations including Kaligandaki-A (144MW), Marshyangdi (69MW), Kulekhani-1\&2 (92MW), Trishuli (24MW), Gandak (15MW), Modi Khola (14.8MW) among others. Publicly held Hydro power companies like Butwal Power Company BPC), Chilime Hydro Power Company (CHPC), Himal Power Limited (HPL) Arun Valley Hydro Power Company Limited (AVHPL), Bhotekoshi Power Company (BKPC) National Hydropower Company Limited ( NHCL), Sanima Hydro Power Limited (SHPL) etc emerged as independent power producers in Nepal and developed power projects like Khimti-I (60MW), Bhotekoshi (36MW), Chilime(20MW) Jhimruk (12MW) Indrawati (7.5MW), Aandhikhola (9.4MW), Piluwa Khola (3MW), Sunkoshi Small (2.5MW) among others. With the entrance of national and foreign private investors in hydro power sector of Nepal, it has considerably changed the dynamics of hydro industry along with Nepalese capital market in which trading of stocks of hydro power companies constitute a major share of total market capitalization.

Even though, Nepalese capital market has considerably extended enough with abundant of investible funds after liberalization initiatives, the frictions in capital market like information asymmetry, faulty incentive 
Funding Gap in Hydropower Projects of Nepal: Does Internal Finance Matter?

design, and moral hazards issues still hinder the sufficient flow of capitals to the power development projects. As is evident from the observation of recent Further Public Offering (FPO) by the nation's largest independent power producer (IPP), Butwal Power Company (BPC), a foreign conglomerate faced the disappointing responses by public as compared to other sectors like micro finance, insurance and BFIs. Most of the power projects in Nepal have long gestation period facing the problems in clearance of Environmental Impact Analysis (EIA), conflict in reimbursement of land with local communities of project affected areas including unjustified demands with provocation from political fronts, unreasonable pressure on construction of infrastructures to local community of project site, unanticipated landslides risks posing significant cost, schedule and environmental challenges, along with sediment loads, both a design challenge and environmental challenge for hydropower development throughout the southern slopes of the Himalayas. All of these risks add construction, maintenance and operation cost of these projects making the private investors reluctant to invest in such risky and long gestation ventures. Hence, in a fierce of energy crisis, the Government of Nepal in its incessant attempt to motivating national and foreign private investors in electricity sector has promulgated Electric Act (1992) and Water Resource Act (1992) with the provisions of income tax rebate, premiums price in Power Purchase Agreement (PPA) for dry seasons, NEA's investment and subsidy in transmission line construction among others. Despite the measures taken to boost up the foreign and private entrepreneurs, financing and investment gaps in power sector persist substantially in Nepal.

Theoretically the private investment decisions in hydro power industry could be explained by the expected future profitability or investment opportunities of power generating companies. Amid huge investment opportunities in hydropower sector of Nepal, companies and private investors show delayed response to this fact which places ground to policy makers and researchers for investigating financing frictions associated with capital markets i.e. supply side constraints of investment. In frictionless capital market, the investment should not be constrained by the financing resources as hypothesized by Modigliani \& Miller (1958) in their seminal works of capital structure theory. Additionally firm's financing policies should not affect the investment decisions, as the internal and external capitals are perfect substitute to each other in which external investors are fully informed about the aspects of production, technology, process, risks and expected future profitability of the new projects. Alternatively a major theoretical departure in investment literatures stems from the work of Fazzari, Hubbard and Peterson (1988) that stress on low explanatory power of Tobin's Q (proxy for future profitability) in investment equation. They empirically test the role of cashflows and find it prominent to explain investment behavior of firms particularly those operating in informational asymmetric capital markets when uncertainty about growth prospects hinder the external providers of funds to invest in firm's projects and internal funds become insufficient to match the investment demand. In external front, banks and financial institutions are in short of long term capital to wait until the cashflows of the long gestation period projects like hydropower that increase the risk of matching maturity time of short term deposits made by the general public. Additionally banks and financing institutions face credit rationing, quotas and restrictions imposed by central bank to invest enough in huge capital demanding projects like hydro power generation. Confronting these capital constraints issues, hydro companies face 
uncertainty in growth prospects, and this uncertainty may be resolved through time as cashflow realizations provide new information. Under such conjectural underpinning, firms with elevated growth uncertainty apparently depend upon their cashflows that contain new information for further investment resulting the firm's investment program spirally sensitive to their internal cashflows. While theoretical argument is well known in investment literatures, its empirical impact on investment cashflow relation has not been analyzed particularly in the context of Nepalese capital market with reference to hydro power sector. Can the link between cashflows and the investment policy of hydro power companies account for observed relationship of financing factors? Do Nepalese power companies face financing constraints in investment of new projects? If so, what is the level of investment cashflows sensitivity of these companies? And after controlling the investment opportunities and leverage effect, do the companies still show the cashflow sensitivity to their investment? This study attempts to answer these questions by analyzing investment cashflows sensitivities of the hydro power companies listed in Nepalese capital market. An equation of firm investment and financing is solved based upon the standard neoclassical investment model with augmented cashflow variable as per the specification proposed by FHP (1988).

\subsection{Data and Sample}

This study adopted the descriptive and analytical research strategy. The main objective of this study is to examine the investment behavior of Nepalese hydro companies and estimate their cashflow coefficients in alternative model specification. For econometric analysis of the relationship among cashflows, investment, and profitability variables, the data should be obtained from the financial reports of the companies. Company annual reports that provide the audited financial statements and information are the most reliable and valid information for the given study purpose. Hence, financial statements are taken out from the sample companies listed in Nepal Stock Exchange limited.

Four sample companies were chosen out of all independent power producers (IPP) engaged in hydro power development in Nepal. These sample companies constituted the majority of total listed hydropower companies in Nepal Stock Exchange (NEPSE) limited. Four out of six listed companies were taken as sample that constitutes $66.67 \%$ of population. However, there were seventy hydro projects by Independent Power Producers (IPPs) generating 483 MW of hydro electricity by 2017AD. (see annex-A) Considering the availability of required data and annual reports of company, the sample chosen for study purpose are; Butwal Power Company (BPC), Chilime Hydro Power Limited (CHPL), Arun Valley Hydro Power Limited (AVHPL) and National Hydro Power Limited (NHPL).

The companies chosen for study and other relevant information about the sample firms has been presented in Table (2). The table depicts that the sample companies have pipelines of huge investment in hydro projects. At least each of the companies is noticed investing in construction and operation of hydro projects either directly or indirectly through joint venture initiation. 
Funding Gap in Hydropower Projects of Nepal: Does Internal Finance Matter?

Table 2- List of sample companies

\begin{tabular}{|c|c|c|c|c|c|}
\hline Sample & $\begin{array}{l}\text { Period } \\
\text { covered }\end{array}$ & $\begin{array}{l}\text { Electricity } \\
\text { Produced }\end{array}$ & Ongoing projects & $\begin{array}{c}\text { Gross investment } \\
\text { proposed }\end{array}$ & $\begin{array}{l}\text { Financing } \\
\text { partners }\end{array}$ \\
\hline $\begin{array}{l}\text { BPCL } \\
(1965)\end{array}$ & $\begin{array}{l}2000-20016 \\
(\mathrm{~N}=18)\end{array}$ & $\begin{array}{l}\text { Tinau Hydro 1MW } \\
\text { Adhikhola-9.4MW } \\
\text { Jhimruk -12MW }\end{array}$ & $\begin{array}{l}\text { Khudi -4MW, Nyadi -30MW } \\
\text { KabeliA-37.6MW,Lower Manang } \\
\text { Marsyangdi -100 MW } \\
\text { Khimti - JV with HPL- } 60 \mathrm{MW} \\
\text { Chino Khola -8.5 MW }\end{array}$ & $\begin{array}{l}\text { Rs } 70 \text { Billion } \\
\text { (approx.) }\end{array}$ & $\begin{array}{l}\text { I F C, W o r l d } \\
\text { Bank, NBL, IBL, } \\
\text { HBL,SBL, CBL, } \\
\text { NIC Asia }\end{array}$ \\
\hline $\begin{array}{l}\text { AVHPL } \\
\text { (1997) }\end{array}$ & $\begin{array}{l}2008-2016 \\
(\mathrm{~N}=9)\end{array}$ & $\begin{array}{l}\text { Piluwa Khola -3 } \\
\text { MW } \\
\text { Ridhi Khola }-2.4 \\
\text { MW }\end{array}$ & $\begin{array}{l}\text { Kabeli B1 -25 MW, Kabeli B1 } \\
\text { cascade Project -9.94 MW, Iwa } \\
\text { Khola -9.9 MW, Upper Khimti } \\
\text { \& khimti Talarace-19MW (JV), } \\
\text { Trishuli -75 MW ( JV) }\end{array}$ & $\begin{array}{l}\text { Rs } 60 \text { Billion or more } \\
\text { (calculated at current } \\
\text { rate per MW) }\end{array}$ & $\begin{array}{l}\text { Bank of } \\
\text { Kathmandu } \\
\text { Machhapuchhre } \\
\text { Bank Limited }\end{array}$ \\
\hline $\begin{array}{l}\text { CHPL } \\
(1996)\end{array}$ & $\begin{array}{l}2004-2016 \\
(\mathrm{~N}=13)\end{array}$ & $\begin{array}{l}\text { Chilime Hydro } \\
-22.1 \mathrm{MW}\end{array}$ & $\begin{array}{l}\text { Rasuwagadhi -111MW } \\
\text { Middle Bhotekoshi -102MW } \\
\text { Sanjhen Upper -14.8 MW } \\
\text { Sanjen Hydro -42.5 MW }\end{array}$ & RS 33.2 Billion & $\begin{array}{l}\text { Staff Provident } \\
\text { Fund }\end{array}$ \\
\hline $\begin{array}{l}\text { NHPL } \\
(1996)\end{array}$ & $\begin{array}{l}2003-2016 \\
(N=13)\end{array}$ & $\begin{array}{l}\text { Indrabati hydro } \\
(7.5 \mathrm{MW})\end{array}$ & $\begin{array}{l}\text { Lower Ikhuwa Hydro } \\
-14.15 \mathrm{MW}\end{array}$ & Rs 2.48 billion & $\begin{array}{l}\text { Nabil bank } \\
\text { consortium Loan }\end{array}$ \\
\hline
\end{tabular}

Source- Company Annual Report (2073/2074)

Study period ranged from 2000 to 2016 AD covering 16 years of balance sheet data for four sample companies but all the observations could not be obtained from each company so the data set constititute unbalanced panel of 64 observations of investment, cashflows, leverage, sales, profitability etc of financial variables. The description of study variables continues in next section.

\subsection{Methods of Analysis}

Standard neoclassical model of investment as developed by Fazzari, Hubbard and Peterson (1988) served as the basic model for this study. The regression specification for examining the investment cashflows sensitivities in asymmetric information framework is obtained using the equation (1) as follows;

$$
(I / K)_{i t}=\beta_{0}+\beta_{1}(X / K)_{i t}+\beta_{2}(C F / K)_{i t}+\epsilon_{i t}
$$

Where $\mathrm{I}_{\mathrm{it}}$ represents net investment in fixed assets for firm $\mathrm{i}$ during period $\mathrm{t}$; and it is the dependent variable in given regression equation. It is obtained as the first difference of tangible fixed assets plus depreciation in present study. X represents a vector of variables, possibly including lagged values, that have been emphasized as determinants of investment from a variety of theoretical perspectives; $\epsilon_{i}$ is an error term. Investment opportunity (X) in equation (1) is an important explanatory variable. Theoretically marginal Q could be used for the approximation of present and expected future investment opportunities. Since marginal Q is unobservable, many investment studies for industrialized countries use average $Q$ as a proxy. However in order to be able to calculate average Q, the country concerned should have a well-developed stock market. 
In Nepal this is still not the case, and only a limited number of hydropower companies are listed and do not have their stock trading regularly. In this study, therefore difference in sales scaled by net fixed assets is used as a proxy for the investment opportunities of the sample firm. This proxy is also used in other studies in transition economies (see e.g.; Lensink and Sterken, 1998, Budina et al, 2004,) and more often it outperforms Tobin's Q (Fazzari et al.1988). Similarly (Abel, 1986), (Gilchrist \& Himmelberg, 1995) have proposed Marginal Profitability of Capital (MPK) as a proxy for investment opportunity. Gilchrist \& Himmelberg (1995) suggest using Sales to Capital(S/K) ratio for approximation of expected marginal profitability of capital (MPK). By applying envelope theorem, they develop MPK as below;

$$
\mathrm{MPK}==\theta(\mathrm{S} / \mathrm{K}) \text {. }
$$

Where $\theta=\left(1+n^{-1}\right) \alpha_{k}, n=(\partial y / \partial p) p / y<-1$ is the firm level price elasticity of demand, $\alpha_{k}$ is the capital share of output from the Cobb-Douglas specification, and $S=\rho / \gamma$ is the firm's sales. Equation (2) shows that, up to a scale parameter, the ratio of sales to capital measures the marginal profitability of fixed capital (MPK). The liquidity coefficient ' $\beta_{2}$ ' depends on the firm's internal cashflow to capital ratio $(\mathrm{CF} / \mathrm{K})$; it represents the potential sensitivity of investment to fluctuations in available internal finance- after investment opportunities are controlled. The liquidity variables are assumed to be uncorrelated with investment opportunities. A positive and significant coefficient of the liquidity variable is thought to indicate that cashflow constraints matter to the extent that investment is sensitive to fluctuations in internal finance but in case of perfect capital market the cashflow coefficient would be insignificantly different from zero. All variables are divided by the beginning of period capital stock ' $\mathrm{K}$ '. Operating cash flow is used as a proxy for the liquidity variable in equation (1).

The baseline regression equation to be estimated in this study has therefore been specified as under;

$$
(I / K)_{i t}=\beta_{0}+\beta_{l}(S / K)_{i t}+\beta_{2}(C F / K)_{i t}+\beta_{3}\left(L e v_{i t}\right)+\epsilon_{i t} \ldots
$$

Where, the dependent variable $\mathrm{I} / \mathrm{K}$ have been specified as the investment in fixed assets scaled by its capital stock at the beginning of the period. The independent variables for the study are specified as;

a) $\mathrm{S} / \mathrm{K}=$ Sales scaled by net fixed assets at beginning of the period. (Gilchrist \& Himmelberg, 1995) (Abel, 1986)etc

b) $\mathrm{CF} / \mathrm{K}=$ Current period Cash flow to the firm as measured by net income plus depreciation during the year scaled by beginning of period value of net fixed assets. The Cash flows variable in empirical investment studies using micro data (Kaplan and Zingales, 1997; Baker, Stein and Wurgle, 2003) has often defined as income plus depreciation and amortization. The rationale behind adding depreciation and amortization back to the bottom line is that these are non-cash expenses.

c) Lev $=$ Leverage or Debt Assets ratio is the measure taken to test the robustness of cashflow coefficient in specification of investment equation. It is another explanatory variable that checks the stability of cashflows measure in our investment equation. Adding the leverage in cashflow investment equation 
Funding Gap in Hydropower Projects of Nepal: Does Internal Finance Matter?

in empirical investment studies of imperfect market has long traditions for example; (Cleary, 1999)

(Fazzari, Hubbard, \& Peterson, 1988) etc.

$\epsilon_{i t}=$ Error term.

For analysis of data and estimation of various regression specifications including Fixed Effect, random Effect and Dynamic Investment Model Gretl statistical software was used. Gretl statistical package is more efficient and easier to test the normality of data and prescribe the endogenity problems in model specification in regression analysis.

\subsection{Analysis and Study Results}

The study of firm specific endogenous shocks to firm's investment decisions is central to corporate finance literatures. Sales, profitability, cashflows, equity and leverage are the major explanatory variables for investment decisions of companies operating in imperfect market. Many investment literatures including (Bernanke, Gertler, \& Gilchrist, 1996 ; Gilchrist \& Himmelberg, 1995; Hoshi, Kashyap, \& Scharfstein, 1991) etc emphasized the volatility of sales and cashflow variables and examined the impact of such uncertainty on investment demand of the firms.

Figure 1- Cyclical variations of study variables over the period 2000-2016 AD
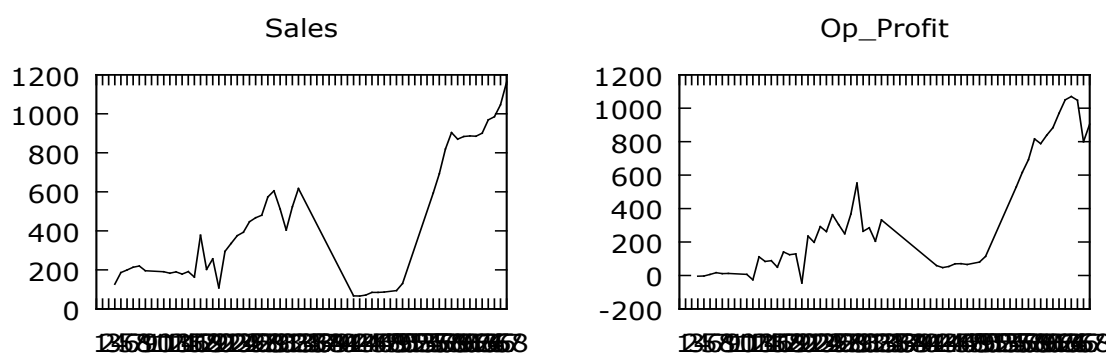

Net_Fixed_Assets

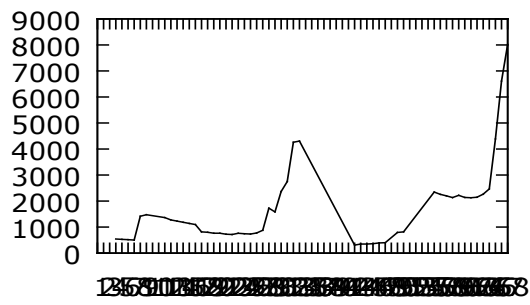

Retained_Earning

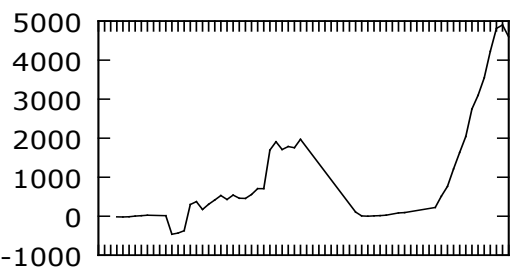

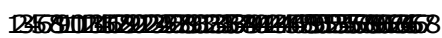

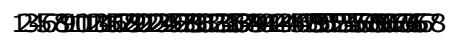

Longterm_Debt

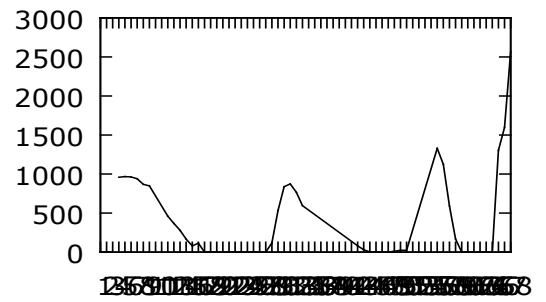

Investment

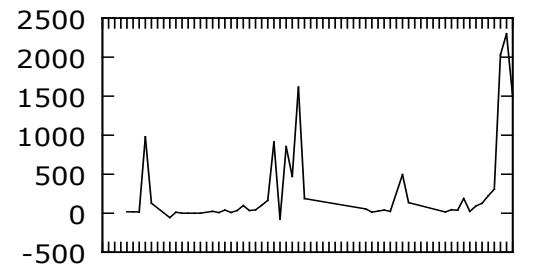

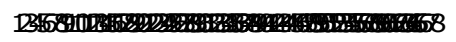

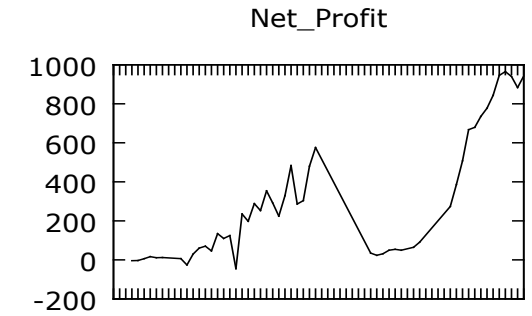

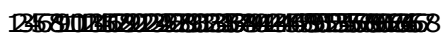

\section{Equity}

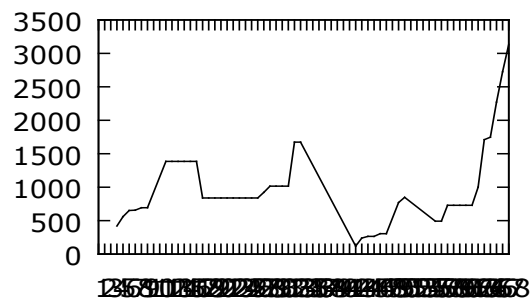

Cashflows

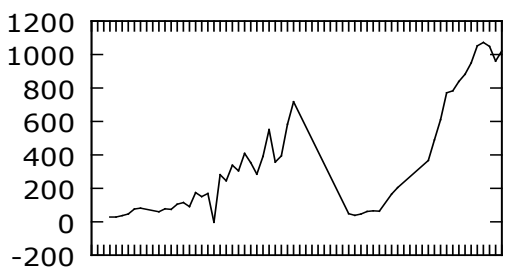

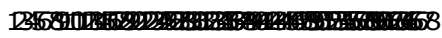


Funding Gap in Hydropower Projects of Nepal: Does Internal Finance Matter?

Business cycles and its countercyclical shocks to the firm's networth are also the well documented facts in firm's growth and investment program. (Abel, 1986). But little empirical knowledge is obtained about the relationship of investment and cyclical variations of cashflows, sales, profitability etc of the hydropower companies.

Figure 1 presents the time specific variations of study variables for sample companies. The X-axis denotes the time period in year and Y-axis is for variable specific fluctuations expressed in million of Rupees. It is interesting enough to observe the relationship between investment and leverage of sample companies which co-proceed with similar path in up and down movements but investment frontier is too sharp while leverage curve too fat and takes sluggish turn around in its movement.

Figure 2- Firm specific investment to capital ratio of sample hydro companies

Inv_K (1)

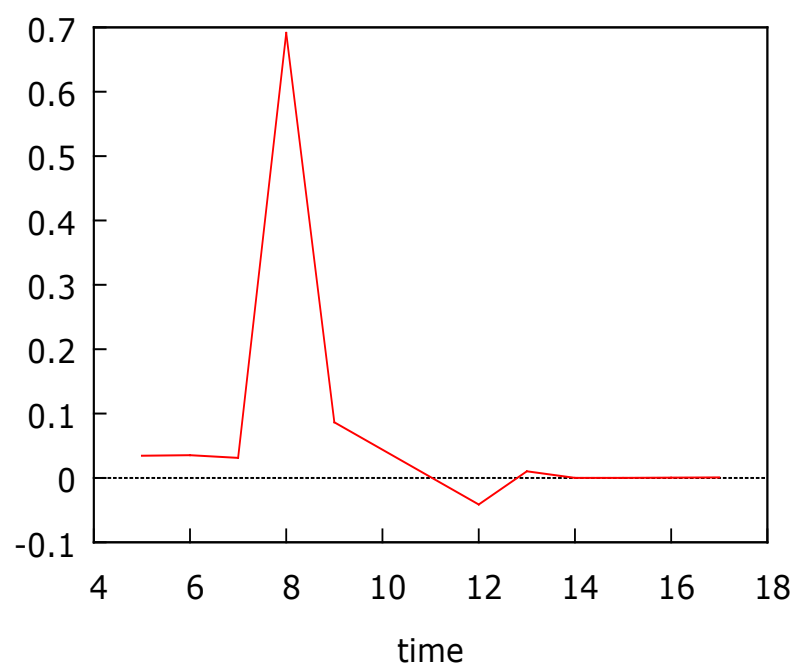

Inv_K (3)

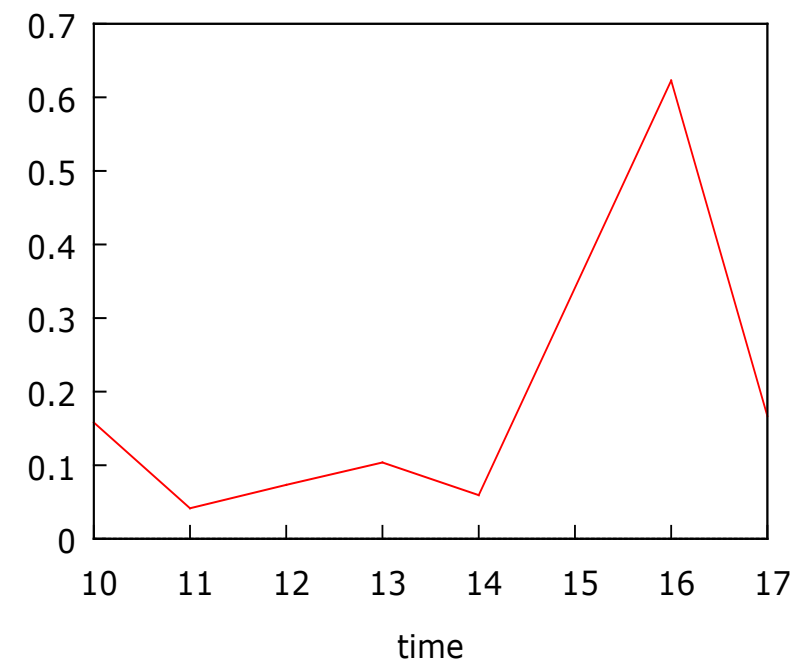

42
Inv_K (2)

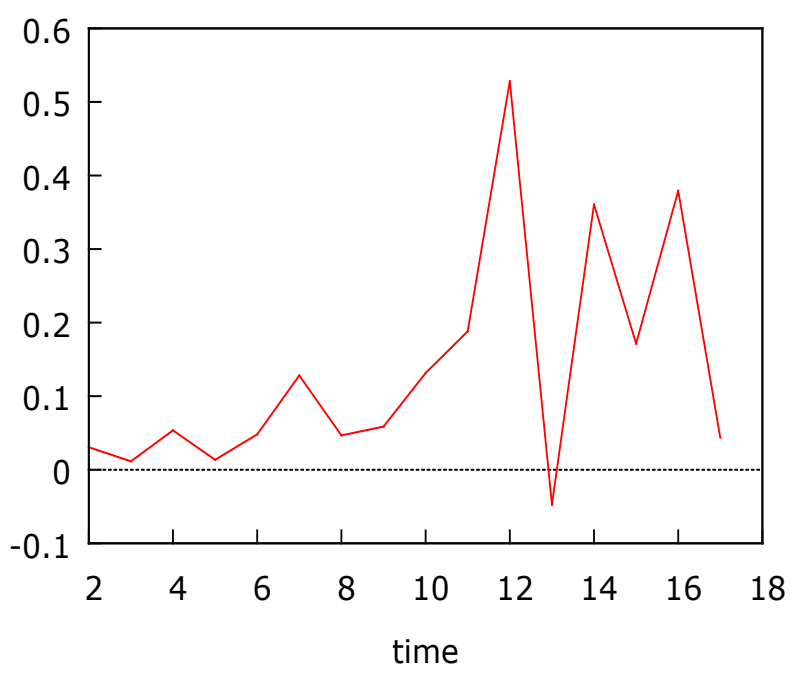

Inv_K (4)

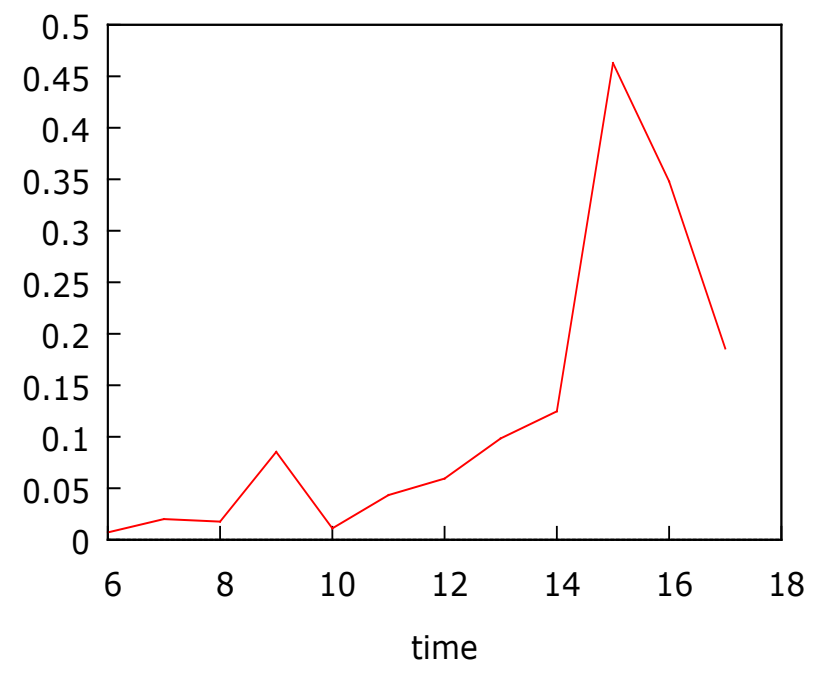

( $)$ The Saptagandaki Journal. All Rights Reserved 
Funding Gap in Hydropower Projects of Nepal: Does Internal Finance Matter?

As noticed in figure 1, the investment path of sample companies took over four major leaps during the interval of study period. But cashflows variables show constant upward movement till the middle of study period which then dumps down for a while and gets again recovery to peak at the subsequent periods. Sales, net fixed assets, operating profit and retained earnings of the sample firms show the similar pattern. One clear implication from the table could be observed that the volatility of study variables extrapolate the trajectory of investment and growth of hydro power industry of Nepal.

The firm specific investment to capital ratio is presented in figure 2 which depicts that companies have investment ratio ranging up to $70 \%$ of its capital stock. It also depicts the hydro companies having investment ratio higher during the decade after 2010 AD. Sample companies have substantial investment growth after 2010 AD except the case of National Hydro Power Company.

\section{Table 4- Summary statistics of study variables}

(Rs in Million and ratios in times)

\begin{tabular}{|c|c|c|c|c|c|c|}
\hline & Variables & Mean & Median & S.D. & Min & Max \\
\hline \multirow{3}{*}{ 苞 } & Sales (Rs) & 430. & 355. & 320. & 66.1 & 1163 \\
\hline & Operating Profit (Rs) & 324. & 201. & 345. & -44.9 & 11170 \\
\hline & Net Profit (Rs) & 296. & 211. & 316. & -44.9 & 965 \\
\hline \multirow{4}{*}{ 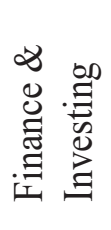 } & Shareholder Equity (Rs) & 981. & 839. & 599. & 120. & 3134 \\
\hline & Long-term Debt (Rs) & 392. & 80.4 & 552. & 0.00 & 2570 \\
\hline & Net Fixed Assets (K) (Rs) & 1657. & 1163 & 1152 & 308. & 8019 \\
\hline & Investment ( I) (Rs) & 289. & 41.9 & 552. & -75.1 & 2300 \\
\hline \multirow{6}{*}{ 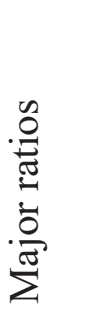 } & $\mathrm{I} / \mathrm{K}$ ratio & 0.124 & 0.056 & 0.172 & -0.047 & 0.691 \\
\hline & ROA ratio & 0.137 & 0.131 & 0.0687 & -0.033 & 0.300 \\
\hline & NP Margin ratio & 0.527 & 0.580 & 0.336 & -0.416 & 1.05 \\
\hline & Leverage ratio & 0.217 & 0.068 & 0.382 & 0.00 & 1.49 \\
\hline & Cashflows/K ratio & 0.218 & 0.170 & 0.142 & -0.003 & 0.558 \\
\hline & Sales/K ratio & 0.293 & 0.243 & 0.141 & 0.118 & 0.609 \\
\hline
\end{tabular}

Table 4 presents the summary statistics of sample firms. Annual electricity sales of sample firms range from Rs 66.1 million to Rs 1163 million with its average value of Rs 430 million. Average investment by companies in study period is noticed Rs 289 million per year (this amount has feasibility of installing approximately $2 \mathrm{MW}$ of hydro electricity plant at current prices). The average capital stocks of sample companies is Rs 1657 million but it ranges from Rs 308 million to Rs 8.019 billion for smallest to largest company. Similarly companies' have average long term debt of Rs 392 million which is $1 / 3^{\text {rd }}$ as compared to their shareholders equity .The table 4 also presented the summary statistics of financial ratios of major study variables. The electricity sales, cashflows, profitability, leverage and investment are the main variables for the study. Sales to capital stock ratio are the proxy for investment opportunities or expected profitability 
of the companies. Alternatively it is the measure of efficiency of fixed capital that translates into the sales revenues. The average sales to capital ratio for sample companies are $29.3 \%$ and its median value is also $24.3 \%$ with $14.1 \%$ standard deviation. It shows that almost all companies over the study period have uniformity in their efficiency of utilization of fixed capital since the deviation among the companies over the period is very minimal. Return on Assets and Net Profit Margin are the ratios that measure profitability in term of Assets and sales volume. The average return on assets for the companies is 13.7 and 13.1 percent both in mean and median values. Similarly the net profit margin for sample companies is more than 50 percent both in mean and median statistics that is encouraging for further investment. Cashflows to capital ratio is the measure for internal financing capacity of the companies. It is considered the main stimuli for investment in imperfect capital market. Due to low cost and freedom of management to utilize it flexibly, most of the companies encourage deploying their internal funds to finance their investment. The mean cashflow to capital ratio is 21.8 percent as compared to its median value 17 percent only. Additionally the average investment to capital ratio for sample companies is 12.4 percent and median value is 5.6 percent only. It shows that the Nepalese hydro companies utilize about 50 percent of their internal cashflows to finance their fixed investment.

\subsection{Regression results}

The diagnostic test for choosing appropriate model estimation i.e. random effect Vs fixed effect model has been considered as the most important process before the regression analysis. The Gretl software allows the diagnostic test of model with following procedures for Hausman Test.

The Hausman test probes the consistency of the GLS estimates. The null hypothesis is that these estimates are consistent - that is, that the requirement of orthogonality of the vi and the $\mathrm{Xi}$ is satisfied. The test is based on a measure, $\mathrm{H}$, of the "distance" between the fixed-effects and random effects estimates, constructed such that under the null it follows the $\mathrm{X}^{2}$ distribution with degrees of freedom equal to the number of timevarying regressors in the matrix $\mathrm{X}$. If the value of $\mathrm{H}$ is "large" this suggests that the random effects estimator is not consistent and the fixed-effects model is preferable. The procedure for calculating $\mathrm{H}$ is given by;

- Treat the random-effects model as the restricted model, and record its sum of squared residuals as SSRr.

- Estimate via OLS an unrestricted model in which the dependent variable is quasidemeaned $y$ and the regressors include both quasi-demeaned X (as in the RE model) and the de-meaned variants of all the time-varying variables (i.e. the fixed-effects regressors); record the sum of squared residuals from this model as $\mathrm{SSRu}$.

- Compute H $=\mathrm{n}(\mathrm{SSR} r-\mathrm{SSRu}$.) /SSRu, where $\mathrm{n}$ is the total number of observations used. On this variant $\mathrm{H}$ cannot be negative, since adding additional regressors to the RE model cannot raise the SSR.

- By default Gretl computes the Hausman test via the regression method (Correl \& Luchheti, 2017) 
Funding Gap in Hydropower Projects of Nepal: Does Internal Finance Matter?

The result of model diagnostic test has been presented in table 5. The table 5 indicates that the Pooled OLS estimation and Random effect estimation are inadequate for estimating the regression values. As shown in first part of the table the p-value is 0.6851 which is more than 5\% level and it rejects the null hypothesis that the pooled OLS model is adequate in favor of the fixed effect model. Similarly the Hausman Test statistics has been calculated in second part of table 5 .

Table 5 Model Diagnostics test results

(using $\mathrm{n}=4$ cross-sectional units)

Fixed effects estimator allows for differing intercepts by cross-sectional unit

\begin{tabular}{|l|l|l|l|l|}
\hline & \multicolumn{1}{|c|}{ coefficient } & \multicolumn{1}{c|}{ std. error } & \multicolumn{1}{c|}{ t-ratio } & \multicolumn{1}{c|}{ p-value } \\
\hline const & 0.173222 & 0.0600993 & 2.882 & $0.0065^{* * *}$ \\
\hline Cashflows/Kt_1 & 0.682539 & 0.250875 & 2.721 & $0.0098^{* * *}$ \\
\hline Sales/K & -0.710754 & 0.209293 & -3.396 & $0.0016^{* * *}$ \\
\hline
\end{tabular}

Residual variance: $0.778071 /(44-6)=0.0204756$

Joint significance of differing group means:

$\mathrm{F}(3,38)=0.499095$ with $\mathrm{p}$-value 0.685137

(A low p-value counts against the null hypothesis that the pooled OLS model is adequate, in favor of the fixed effects alternative.)

Random effects estimator allows for a unit-specific component to the error term

\begin{tabular}{|l|l|l|l|l|l|}
\hline & \multicolumn{1}{|c|}{ Coefficient } & \multicolumn{1}{c|}{ std. error } & \multicolumn{1}{c|}{ t-ratio } & \multicolumn{1}{c|}{ p-value } & \\
\hline Const & 0.174096 & 0.0500010 & 3.482 & 0.0012 & $* * *$ \\
\hline Cashflows/Kt_1 & 0.588829 & 0.192287 & 3.062 & 0.0039 & $* * *$ \\
\hline Sales/K & -0.642242 & 0.197627 & -3.250 & 0.0023 & $* * *$ \\
\hline
\end{tabular}

Hausman test statistic:

$\mathrm{H}=1.66763$ with $\mathrm{p}$-value $=\operatorname{prob}($ chi-square $(2)>1.66763)=0.434389$

(A low p-value counts against the null hypothesis that the random effects model is consistent, in favor of the fixed effects model.)

The null hypothesis is that the Random Effect Model is consistent, in favor of the Fixed Effect Model. But the P-Statistics in this test shows the value higher than 0.05 with chi-square (2) value 1.6676 suggest rejecting the null hypothesis. Consequently Fixed Effect Model has been considered as consistent and adequate predictor for the hypothesized relationship of cashflows- investment sensitivity of Nepalese hydro power companies. The regression results for fixed effect model are presented in table 6 . 
Funding Gap in Hydropower Projects of Nepal: Does Internal Finance Matter?

Table 6: Cashflow effect on investment (Fixed-effects, using 44 observations)

Included 4 cross-sectional units

Time-series length: minimum 6, maximum 16

Dependent variable: Inv/K

\begin{tabular}{|l|c|c|c|c|l|}
\hline & Coefficient & Std. Error & t-ratio & p-value & \\
\hline Const & 0.142703 & 0.0583375 & 2.446 & 0.0193 & $* *$ \\
\hline Cashflows/K & 0.921764 & 0.258482 & 3.566 & 0.0010 & $* * *$ \\
\hline Sales/K & -0.917057 & 0.216796 & -4.230 & 0.0001 & $* * *$ \\
\hline Leverage & 0.198560 & 0.0849864 & 2.336 & 0.0250 & $* *$ \\
\hline
\end{tabular}

\begin{tabular}{|c|c|c|c|}
\hline Mean dependent var. & 0.115982 & S.D. dependent var. & 0.156079 \\
\hline Sum squared residual & 0.678040 & S.E. of regression & 0.135371 \\
\hline LSDV R-squared & 0.352710 & Within R-squared & 0.343682 \\
\hline $\operatorname{LSDV~F}(6,37)$ & 3.360228 & P-value(F) & 0.009593 \\
\hline Log-likelihood & 29.36697 & Akaike criterion & -44.73394 \\
\hline Schwarz criterion & -32.24461 & Hannan-Quinn & -40.10230 \\
\hline Rho & -0.206401 & Durbin-Watson & 2.306522 \\
\hline
\end{tabular}

Joint test on named regressors -

Test statistic: $F(3,37)=6.45838$

With p-value $=\mathrm{P}(\mathrm{F}(3,37)>6.45838)=0.00125689$

The first part of the Table (6) has presented the coefficient of cashflows, leverage and sales as the hypothesized predictors of the given investment model. The leverage has been added to investment equation to measure the stability of cashflow coefficient in the given specification. It confirms the robustness of liquidity variable in explaining investment behavior of firms. As per the priori expectation, cashflows and leverage have significant impact on investment decisions of hydro companies. The cashflow coefficient is positively larger and significant at $1 \%$ level. It indicates that the investment decision of hydro companies has been constrained by the capital market frictions. The larger and positive cashflow coefficient indicates the severity of information or moral hazards problem in capital market.

Test for differing group intercepts has been performed for fixed effect model. The null hypothesis was that the groups have a common intercept. The result of the test statistic is $\mathrm{F}(3,37)=6.4583$ with $\mathrm{p}$-value $=$ $\mathrm{P}(\mathrm{F}(3,37)>6.4583)=0.001256$. The significance $\mathrm{p}$-value of $\mathrm{F}(3,37)$ test statistic indicates that the groups have a differing group intercepts. Meaning that fixed effect model is suggested for the data set. 
Funding Gap in Hydropower Projects of Nepal: Does Internal Finance Matter?

Table 7: Cashflow Effect on Investment using lagged investment as predictor

Included 4 cross-sectional units

Time-series length: minimum 5, maximum 15

Dependent variable: Inv/K

\begin{tabular}{|c|c|c|c|c|c|}
\hline & Coefficient & Std. Error & t-ratio & p-value & \\
\hline Const & 0.168156 & 0.0738552 & 2.277 & 0.0296 & $* *$ \\
\hline Cashflows/K & 0.885587 & 0.278236 & 3.183 & 0.0032 & $* * *$ \\
\hline Sales/K & -0.948033 & 0.243520 & -3.893 & 0.0005 & $* * *$ \\
\hline Leverage & 0.234944 & 0.101765 & 2.309 & 0.0276 & $* *$ \\
\hline $\mathrm{Inv} / \mathrm{K}_{\mathrm{t}-1}$ & -0.0568641 & 0.140443 & -0.4049 & 0.6883 & \\
\hline Mean dependent var. & \multicolumn{2}{|c|}{0.121821} & \multicolumn{2}{|c|}{ S.D. dependent var. } & 0.161611 \\
\hline Sum squared resid. & \multicolumn{2}{|c|}{0.645433} & \multicolumn{2}{|c|}{ S.E. of regression } & 0.142020 \\
\hline LSDV R-squared & \multicolumn{2}{|c|}{0.366355} & \multicolumn{2}{|c|}{ Within R-squared } & 0.354559 \\
\hline $\operatorname{LSDV} F(7,32)$ & \multicolumn{2}{|c|}{2.643067} & \multicolumn{2}{|c|}{ P-value(F) } & 0.028277 \\
\hline Log-likelihood & \multicolumn{2}{|c|}{25.77673} & \multicolumn{2}{|c|}{ Akaike criterion } & -35.55346 \\
\hline Schwarz criterion & \multicolumn{2}{|c|}{-22.04242} & \multicolumn{2}{|c|}{ Hannan-Quinn } & -30.66829 \\
\hline Rho & \multicolumn{2}{|c|}{-0.160197} & \multicolumn{2}{|c|}{ Durbin-Watson } & 2.155715 \\
\hline
\end{tabular}

Joint test on named regressors -

Test statistic: $\mathrm{F}(4,32)=4.39463$

With $p$-value $=\mathrm{P}(\mathrm{F}(4,32)>4.39463)=0.00605372$

Test for normality of residual -

Null hypothesis: error is normally distributed

Test statistic: Chi-square(2) $=21.9894$

With p-value $=1.67904 \mathrm{e}-005$

Distribution free Wald test for heteroskedasticity -

Null hypothesis: the units have a common error variance

Asymptotic test statistic: Chi-square $(4)=5751.84$

With p-value $=0$

Table 7 presents the results from equation (3) that includes the lagged investment variable to examine its effect on firm investment decisions besides the leverage. When lagged investment variable included in the set of expounding variables, the explanatory power of regression model improved more. The results from the fixed effect model indicate that the value of $\mathrm{R}^{2}$ and adjusted $\mathrm{R}^{2}$ are 0.3663 and 0.3545 respectively. The overall explanatory power of the regression model looks good with $\mathrm{R}^{2}$ of 0.3663 . The result implies that about $36.63 \%$ change in investment rate is explained by the variations in explanatory variables, denoting that the regression has good fit and is reliable. In the model, F statistics is 4.3946 and its p-value (F Sig.) is 
0.006, which signify that the model is fairly fitted well statistically. Because, the F-statistic, a measure of the overall significance of the regression, shows that the explanatory variables employed are significant at the $1 \%$ level, which is supported by low standard error of regression equation signifying minimized sum of squared error.

The distribution free Wald test for heteroskedasticity has been performed fixed effect model. The null hypothesis was that the units have common error variances. Asymptotic test statistic: Chi-square (4) $=5751.84$, with $\mathrm{p}$-value $=0.000$ indicates that there is no heteroskedasticity because null hypothesis is accepted. Likely, Durbin-Watson statistic $=2.1557$ with $p$-value $=0.002827$ indicates that there is no autocorrelation problem in the data set. Test for normality of residuals has been performed for fixed effect model. The null hypothesis was that the errors are normally distributed. The result of the test statistic is Chi-square $(2)=21.9894$ with $p$-value $=0.0000$. The significance $p$-value of test statistic indicates that the errors are normally distributed. Meaning that fixed effect model is good fit for the data set.

The empirical finding of the fixed effect model suggests that there is positive and statistically significant relationship between fixed investment spending and internal cashflows of hydro power companies of Nepal. The cashflow variable is found statistically significant with same direction of relationship with investment variable using fixed effects model. The result is as expected and consistent with (Fazzari, Hubbard, \& Peterson, 1988; Hoshi, Kashyap, \& Scharfstein, 1991; Hu \& Schiantarelli, 1998) where they have found that investment decisions of financially constrained firms are more sensitive to their internal cashflows since their inability or reluctances to go external capital markets to obtain as much funds as they need for investment. Moreover, the result is justified as on the reason that leverage coefficient are positive but smaller significantly smaller than the cashflow coefficient in explaining investment decisions of Nepalese firms.

Sales to Capital ratio (Sales/K) are found significantly negatively associated with investment decision using fixed effect model. The result is significant at $1 \%$ level of significance. The result indicates that hydropower companies do increase investment even in decrease of their sales in Nepalese context. This result is contrary to priori expectation and is also inconsistent to (Hoshi, Kashyap, \& Scharfstein, 1991; Fazzari, Hubbard, \& Peterson, 1988) where they found positive association between investment and sales as the proxy for future expected profitability. The possible reason of such contrary result could be justified on ground that Nepalese hydropower companies do make contract with NEA to sell their electricity at an agreed price with PPA prior to project installation phase and volume of electricity sales determined accordingly. Leverage is found positively associated with investment decisions of Nepalese hydro companies. The leverage coefficient is significant at 5\% level of significance. It indicates that Nepalese hydro companies' investment decisions are positively associated with leverage decisions. It indicates that the companies with access to bank or financial institutions should have higher investment ratio than the companies without leverage access. Moreover, with the inclusion of leverage ratio in investment model, the cashflow variable shows the stable and consistent implication on investment. It supports the prior studies of (Cleary, 1999; Pradhan \& Kurmi, 2004; Subedi, 2008) among others. 


\subsection{Conclusion}

This study examined the determinants of fixed investment decisions of Nepalese hydro companies listed in the Nepal Stock Exchange. The descriptive and causal comparative research designs have been adopted for the study. The pooled OLS, fixed effect and random effect model have been used to examine the determinants of investment policy of hydro companies. The panel data of 4 hydro companies over the period of 2000 to 2016 have been collected from the annual reports of the companies in sample. The dependent variable used in the study is investment to capital ratio and independent variables are: sales to capital ratio, cashflows to capital ratio, leverage, and lagged investment.

The estimated regression models reveal that cashflows to capital ratio has positive and statistically significant impact on hydro investment decisions. Leverage is found significantly positively associated with investment decision. However, sales to capital ratio and lagged investment seem negative in explaining the variation of investment. Eventually, this study concludes that the major determinants of hydro companies' investment decisions are internal cashflows, and leverage or loan from the banks and financial institutions in Nepalese context.

This study offers the following recommendations based on the findings from the empirical analysis. Firstly, Nepalese hydro companies have nominal levels of investment which can pose a significant impediment to fulfill the demand of hydropower development in Nepal. Moreover, the hydro companies show their interdependency to their internal cashflows for financing their new investment projects. This relationship strongly supports the financing constraints hypothesis that indicates the capital market frictions as the major obstacle of hydro investment in Nepal. Although the companies have access to banks and foreign capital, still the financing gaps persist and they highly depend on their own cashflows for investment. Hence, the government should ensure with appropriate policies, procedures, information systems and regulatory mechanism that enable well functioning of capital markets to efficient flows of funds either in the form of equity or debt to the hydropower investment projects of Nepal.

Finally, the volatility of cashflows and sales of hydro companies along with their long gestation period pose a significant credit risk to banks and lending institutions that hinder them to provide as much credit as they demand. Moreover, the cyclical variations in net worth and collateral values of hydro companies during the tough economic period also resist them to obtain enough finance for further investment. Consequently, it is highly worth mentioning to develop the hedging mechanism in hydro investment for mitigating the default risk associated with variations in cashflows and reductions in collateral values during the downturn of economic activities. When hedging mechanism works, it would permit the extension of debt capacity of hydro companies enabling them to boost up the huge investment for generation of energy as per the power demand of nation. 


\section{References;}

Abel, A. B. \& Blanchard, O.J. (1986). Investment and sales: Some empirical evidence, NBER .retrieved from http://www.archive.org/details/investmentsalessOOabel.

Bernanke, B., Gertler, M., \& Gilchrist, S. (1996). The financial accelerator and flight to quality. The Review of Economics \& Statistics, 78 (1), 1-15.

Bond, S., \& Meghir, C. (1994). Dynamic investment model and firm's financial policy. The Review of Economic Studies , 61(2), 197-222.

Chatelain, J. B. (2003). Structural Modelling of financial constraints on investment: Where do we stand? In P. a. Butzen, Firms Investment and Finance Decision, Edward Elgar, pp.40-58, 2003.

Cleary, S. (1999). The relationship between firm investment and financial status. Journal of Finance, 54(2), 673-692.

Coase, R. (1937). The Nature of the firm. Economica , 4(16), 386-405.

Correl, A., \& Luchheti, R. (2017). Gretl User's Guide. Wake Forest University: Gnu Regression, Econometrics and Time-series Library.

Fazzari, S., Hubbard, G., \& Peterson. (1988). Financing constraints and corporate investment. Brooking Papers on Economic Activity, 1, 141-206.

Gilchrist, S., \& Himmelberg, C. (1995). Evidence on the role of cashflow for investment. Journal of Monetary Economics , 36 (3),541-572.

Hoshi, T., Kashyap, A., \& Scharfstein, D. (1991). Corporate structure, liquidity, and investment: Evidence from Japanese panel data. Quarterly Journal of Economics ,106 (1), 33-60.

Hu, X., \& Schiantarelli, F. (1998). Investment and capital market imperfections; A switching regression approach using US firm panel data. The Review of Economics and Statistics, 53, 466-479.

Hubbard, G. (1998). Capital market imperfections and investment. Journal of Economic Literature , 36(1), 193-225.

Lary, L., Ofek, E., \& Stulz, R. (1996). Levarage, investment and firm growth. Journal of Financial Economics , 40(1), 3-30.

Levine, R., \& Renelt, D. (1992). A sensitivity analysis of cross country growth regression. The American Economic Review, 82(4), 942-963.

Ministry of Finance. (2074). Economic Survey. Kathmandu: Ministry of Finance.

Pradhan, R. S., \& Kurmi, M. P. (2004). A Relationship between firm investment and financial status of Nepalese enterprises. Journal of Management and Development Review, 1(1), 9-16.

Subedi, K.D. (2008). Corporate investment and financing constraints; the Nepalese evidences. (Unpublished M.Phil Dissertation), Faculty of Management, Tribhuvan University, Kathmandu.

Willimson, O.E. (1975). Markets and hierarchies: analysis and antitrust implications. New York Free Press . 
Funding Gap in Hydropower Projects of Nepal: Does Internal Finance Matter?

\section{Annex - 1}

IPPs' Hydro Power Projects (Operation)

\begin{tabular}{|c|c|c|c|c|c|c|}
\hline S.N. & Developer & Projects & Location & $\begin{array}{c}\text { Capacity } \\
\text { (kW) }\end{array}$ & PPA Date & $\begin{array}{c}\text { Commercial } \\
\text { Operation Date }\end{array}$ \\
\hline 1 & Himal Power Ltd. & Khimti Khola & Dolkha & 60000 & 2052.10 .01 & 2057.03 .27 \\
\hline 2 & Bhotekoshi Power company Ltd. & Bhotekoshi Khola & Sindhupalchowk & 45000 & 2053.04 .06 & 2057.10 .11 \\
\hline 3 & Syange Electricity Company Limited & Syange Khola & Lamjung & 183 & 2058.10 .03 & 2058.10 .10 \\
\hline 4 & National Hydro Power Company Ltd. & Indrawati - III & Sindhupalchowk & 7500 & 2054.08 .15 & 2059.06 .21 \\
\hline 5 & Chilime Hydro Power Company Ltd. & Chilime & Rasuwa & 22100 & 2054.03 .11 & 2060.05 .08 \\
\hline 6 & Butwal Power Company Ltd. & Jhimruk Khola & Pyuthan & 12000 & 2058.03 .29 & 1994 \\
\hline 7 & Butwal Power Company Ltd. & Andhi Khola & Syangza & 9400 & 2058.03 .29 & 2071.12 .22 \\
\hline 8 & Arun Valley Hydropower Development Co. (P.) Ltd. & Piluwa Khola Small & Sankhuwasabha & 3000 & 2056.10 .09 & 2060.06 .01 \\
\hline 9 & Rairang Hydro Power Development Co. (P) Ltd. & Rairang Khola & Dhading & 500 & 2059.08 .27 & 2061.08 .01 \\
\hline 10 & Sanima Hydropower (Pvt.) Ltd. & Sunkoshi Small & Sindhupalchok & 2500 & 2058.07 .28 & 2061.12 .11 \\
\hline 11 & Alliance Power Nepal Put.Ltd. & Chaku Khola & Sindhupalchok & 3000 & 2056.11 .03 & 2062.03 .01 \\
\hline 12 & Khudi Hydropower Ltd. & Khudi Khola & Lamjung & 4000 & 2058.03 .04 & 2063.09 .15 \\
\hline 13 & Unique Hydel Co. Pvt.Ltd. & Baramchi Khola & Sindhupalchowk & 4200 & 2058.12 .14 & 2063.09 .27 \\
\hline 14 & Thoppal Khola Hydro Power Co. Pvt. Ltd. & Thoppal Khola & Dhading & 1650 & 2059.11 .23 & 2064.07 .13 \\
\hline 15 & Gautam Buddha Hydropower (Pvt.) Ltd. & Sisne Khola Small & Palpa & 750 & 2061.04 .29 & 2064.06 .01 \\
\hline 16 & Kathmandu Small Hydropower Systems Pvt. Ltd. & Sali Nadi & Kathmandu & 250 & 2062.04 .24 & 2064.08 .01 \\
\hline 17 & Khoranga Khola Hydropower Dev. Co. Pvt. Ltd. & Pheme Khola & Panchtar & 995 & 2057.12 .31 & 2064.08 .05 \\
\hline 18 & Unified Hydropower (P.) Ltd. & Pati Khola Small & Parbat & 996 & 2062.10 .28 & 2065.10 .27 \\
\hline 19 & Task Hydropower Company (P.) Ltd. & Seti-II & Kaski & 979 & 2063.06 .08 & 2065.11 .14 \\
\hline 20 & Ridi Hydropower Development Co. (P.) Ltd. & Ridi Khola & Gulmi & 2400 & 2063.05 .08 & 2066.07 .10 \\
\hline 21 & Centre for Power Dev. And Services (P.) Ltd. & Upper Hadi Khola & Sindhupalchowk & 991 & 2064.04 .07 & 2066.07 .22 \\
\hline 22 & Gandaki Hydro Power Co. Pvt. Ltd. & Mardi Khola & Kaski & 4800 & 2060.07 .07 & 2066.10 .08 \\
\hline 23 & Himal Dolkha Hydropower Company Ltd. & Mai Khola & Ilam & 4500 & 2063.11 .19 & 2067.10 .14 \\
\hline 24 & Baneswor Hydropower Pvt. Ltd. & Lower Piluwa Small & Sankhuwasabha & 990 & 2064.07 .21 & 2068.04 .01 \\
\hline 25 & Barun Hydropower Development Co. (P.) Ltd. & Hewa Khola & Sankhuwasabha & 4455 & 2061.04 .02 & 2068.04 .17 \\
\hline 26 & Bhagawati Hydropower Development Co. (P.) Ltd. & Bijayapur-1 & Kaski & 4410 & 2066.03 .30 & 2069.05 .04 \\
\hline 27 & Kathmandu Upatyaka Khanepani bewasthapan Board & Solar & Lalitpur & 680.4 & 2069.06 .12 & 2069.07 .15 \\
\hline 28 & Nyadi Group (P.) Ltd. & Siuri Khola & Lamjung & 4950 & 2064.04 .17 & 2069.07 .30 \\
\hline 29 & United Modi Hydropwer Pvt. Ltd. & Lower Modi 1 & Parbat & 10000 & 2065.10 .20 & 2069.08 .10 \\
\hline 30 & Synergy Power Development (P.) Ltd. & Sipring Khola & Dolkha & 9658 & 2065.10 .20 & 2069.10 .03 \\
\hline 31 & Laughing Buddha Power Nepal (P.) Ltd. & Middle Chaku & Sindhupalchowk & 1800 & 2066.11 .03 & 2069.11 .15 \\
\hline 32 & Aadishakti Power Dev. Company (P.) Ltd. & Tadi Khola (Thaprek) & Nuwakot & 5000 & 2061.12 .15 & 2069.12 .14 \\
\hline 33 & Ankhu Khola Jal Bidhyut Co. (P.) Ltd. & Ankhu Khola - 1 & Dhading & 8400 & 2066.02 .22 & 2070.05 .05 \\
\hline 34 & Nepal Hydro Developer Pvt. Ltd. & Charanawati Khola & Dolakha & 3520 & 2067.01 .13 & 2070.02 .24 \\
\hline 35 & Laughing Buddha Power Nepal Pvt. Ltd. & Lower Chaku Khola & Sindhupalchowk & 1800 & 2063.07 .02 & 2070.04 .24 \\
\hline 36 & Bhairabkunda Hydropower Pvt. Ltd. & Bhairab Kunda & Sindhupalchowk & 3000 & 2065.08 .02 & 2071.02 .22 \\
\hline 37 & Radhi Bidyut Company Ltd. & Radhi Khola & Lamjung & 4400 & 2066.10 .18 & 2071.02 .31 \\
\hline 38 & Pashupati Environmental Eng. Power Co. Pvt. Ltd. & Chhote Khola & Gorkha & 993 & 2067.11 .09 & 2071.03 .09 \\
\hline 39 & Mailung Khola Hydro Power Company (P.) Ltd. & Mailung Khola & Rasuwa & 5000 & 2058.04 .09 & 2071.03 .19 \\
\hline 40 & Joshi Hydropower Development Company Limited & Upper Puwa -1 & Illam & 3000 & 2066.01 .23 & 2071.10 .01 \\
\hline 41 & Sanima Mai Hydropower Limited & Mai Khola & Ilam & 22000 & 2067.01 .08 & 2071.10 .14 \\
\hline 42 & Bojini Company Private Limited & Jiri Khola Small & Dolkha & 2200 & 2065.10 .23 & 2071.11 .01 \\
\hline 43 & Ruru Hydropower Project (P) Ltd. & Upper Hugdi Khola & Gulmi & 5000 & 2066.04 .04 & 2071.12 .09 \\
\hline 44 & Prime Hydropower co. Pvt. Ltd. & Belkhu & Dhading & 518 & 2064.04 .04 & 2071.12 .30 \\
\hline 45 & Api Power Company Pvt. Ltd. & Naugadh gad Khola & Darchula & 8500 & 2067.01 .19 & 2072.05 .02 \\
\hline 46 & Kutheli Bukhari Small Hydropower (P).Ltd & Suspa Bukhari & Dolakha & 998 & 2069.04 .32 & 2072.06 .03 \\
\hline 47 & Sanima Mai Hydropower Ltd. & Mai Cascade & Ilam & 7000 & 2069.10 .12 & 2072.10 .29 \\
\hline
\end{tabular}


Funding Gap in Hydropower Projects of Nepal: Does Internal Finance Matter?

\begin{tabular}{|c|c|c|c|c|c|c|}
\hline 48 & Chhyangdi Hydropower Limited & Chhandi & Lamjung & 2000 & 2068.12 .23 & 2072.12 .13 \\
\hline 49 & $\begin{array}{l}\text { Panchakanya Mai Hydropower Ltd. (Previously Mai Valley and } \\
\text { prior to that East Nepal) }\end{array}$ & Upper Mai Khola & Ilam & 9980 & 2061.12.19 & 2073.03 .09 \\
\hline 50 & Sayapatri Hydropower Private Limited & Daram Khola A & Baglung & 2500 & 2068.12 .19 & 2073.03 .12 \\
\hline 51 & Electro-com and Research Centre Pvt. Ltd. & Jhyadi Khola & Sindhupalchowk & 2000 & 2067.01 .30 & 2073.05 .31 \\
\hline 52 & Khani Khola Hydropower Company Pvt. Ltd. & Tungun-Thosne & Lalitpur & 4360 & 2069.04 .05 & 2073.07 .09 \\
\hline 53 & Daraudi Kalika Hydro Pvt. Ltd. & Daraudi Khola A & Gorkha & 6000 & 2068.05 .19 & 2073.08 .13 \\
\hline 54 & Khani Khola Hydropower Company Pvt. Ltd. & Khani Khola & Lalitpur & 2000 & 2069.04 .05 & 2073.08 .20 \\
\hline 55 & Sapsu Kalika Hydropower Co. Pvt. Ltd. & Miya Khola & Khotang & 996 & 2069.08 .10 & 2073.09 .03 \\
\hline 56 & Sinohydro-Sagarmatha Power Company (P) Ltd. & Upper Marsyangdi "A" & Lamjung & 50000 & 2067.09 .14 & 2073.09 .17 \\
\hline 57 & Madi Power Pvt. Ltd. & Upper Madi & Kaski & 25000 & 2066.05 .21 & 2073.09 .25 \\
\hline 58 & Panchthar Power Company Pvt. Ltd. & Hewa Khola A & Panchthar & 14900 & 2068.05 .30 & 2073.10 .22 \\
\hline 59 & Sanvi Energy pvt. Ltd. & Jogmai & Ilam & 7600 & 2069.08 .07 & 2074.01 .18 \\
\hline 60 & Bhugol Energy Dev Compay (P). Ltd & Dwari Khola & Dailekha & 3750 & 2069.12 .30 & 2074.1 .23 \\
\hline 61 & Mai Valley Hydropower Private Limited & Upper Mai C & Ilam & 5100 & 2068.12 .23 & 2074.04 .09 \\
\hline 62 & Dronanchal Hydropower Co.Pvt.Ltd & Dhunge-Jiri & Dolakha & 600 & 2068.09 .25 & 2074.06 .01 \\
\hline 63 & Dibyaswari Hydropower Limited & Sabha Khola & Sankhuwasabha & 4000 & 2068.11 .17 & 2074.06 .02 \\
\hline 64 & Puwa Khola-1 Hydropower P. Ltd. & Puwa Khola -1 & Ilam & 4000 & 2070.10 .09 & 2074.06 .23 \\
\hline 65 & Shibani Hydropower Co. Pvt. Ltd. & Phawa Khola & Taplejung & 4950 & 2063.12 .01 & 2074.07 .14 \\
\hline 66 & Mount Kailash Energy Pvt. Ltd. & Thapa Khola & Myagdi & 13600 & 2067.10 .11 & 2074.08 .22 \\
\hline 67 & Mandakini Hydropower Limited & Sardi Khola & Kaski & 4000 & 2068.11 .11 & 2074.08 .23 \\
\hline 68 & Garjang Upatyaka Hydropower (P.) Ltd. & Chake Khola & Ramechhap & 2830 & 2065.11 .06 & 2074.08 .28 \\
\hline 69 & Union Hydropower Pvt Ltd. & Midim Karapu & Lamjung & 3000 & 2069.10 .28 & 2074.10 .15 \\
\hline \multirow[t]{2}{*}{70} & Syauri Bhumey Microhydro Project & Syauri Bhumey & Nuwakot & 23 & 2072.11 .16 & 2074.10 .18 \\
\hline & & & TOTAL & $483,155,40$ & & \\
\hline
\end{tabular}

\section{Annex - 2}

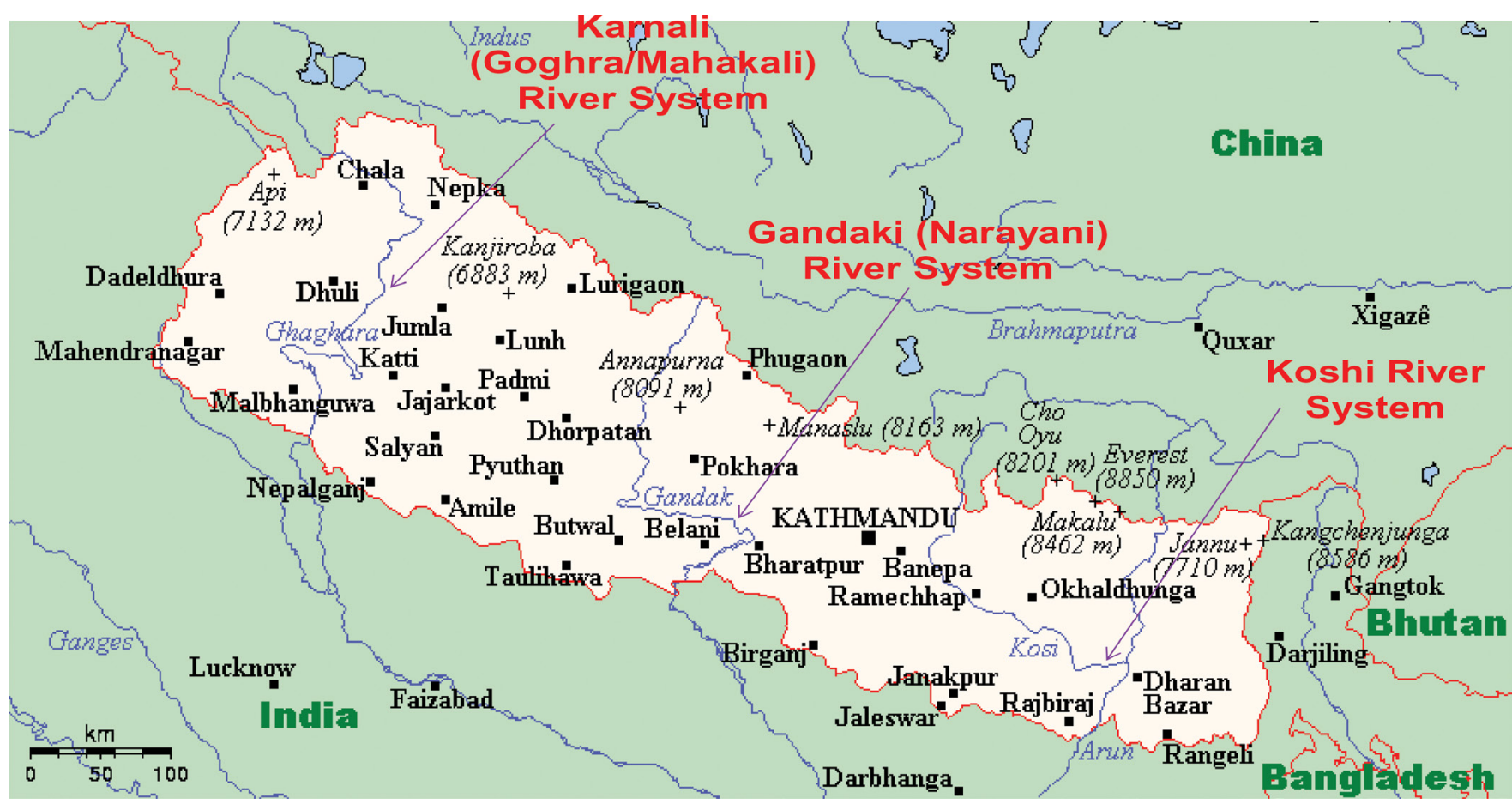

Source: Wekipedia, accessed on 12 November 2016 from https://en.wikipedia.org/wiki/Geography_of_Nepal 